\title{
INNER STRUCTURE AND LOCAL WISDOM IN NYANGAHATN BABURUKNG ORAL TRADITION OF DAYAK KANAYATN
}

\author{
STRUKTUR BATIN DAN KEARIFAN LOKAL DALAM NYANGAHATN BABURUKNG \\ TRADISI LISAN DAYAK KANAYATN
}

\author{
Sesilia Seli \\ Fakultas Keguruan dan Ilmu Pendidikan Universitas Tanjungpura \\ Jalan Prof. Dr. H. Hadari Nawawi, Pontianak, West Kalimantan, Indonesia \\ sesilia.seli@fkip.untan.ac.id
}

(Naskah diterima tangga 6 April 2021, direvisi terakhir tanggal 25 September 2021, dan disetujui tanggal 2 Desember 2021)

DOI: https:/ / doi.org/10.26499/wdprw.v49i2.816

\begin{abstract}
Nyangahatn Baburukng is the mantra of the Kanayatn Dayak community that is uttered at the Baburukng ritual as the initial stage of the farming tradition (bahuma). This study was conducted to provide a deeper meaning to the inner structure and local wisdom of the Nyangahatn Baburukng and as a means of inheritance to the next generation. The objective of this study is to analyze the inner structure and forms of local wisdom in Nyangahatn Baburukng. The study is based on theories of local wisdom, mantra, and structure of mantra by using qualitative descriptive methods, objective approaches and sociology of literature. The results of this study indicate that the inner structure of the Nyangahatn Baburukng text includes (1) The theme includes belief in Jubata as a helper and giver of blessings; carefully reading the signs of nature (listening to the sound of the bird/ rasi) to determine the type of land suitable for farming (bahuma); offerings as a means to communicate with Jubata, ghosts, demons/devils; and offerings as symbols of gratitude, sacrifice, restoration of relationships, purity, and sincerity. (2) The tone includes the tone of gratitude, the tone of surrender, the tone of the sacred; pleading tone, friendly tone, and hopeful tone. (3) Feelings include feelings of joy, optimism, cooperation, togetherness, solidarity, and full of blessings. (4) Mantra's mandate includes that humans must be able to establish good communication with Jubata, the spirits of the ancestors, and the devil so that they can coexist and not be disturbed by the power of the devil; the implementation of the Baburukng ritual is a form of obedience to tradition and complete surrender to Jubata; cooperation, togetherness, and high solidarity need to be preserved. The forms of local wisdom in the Nyangahatn Baburukng text include (1) local knowledge; (2) local values; (3) local skills and technology; and (4) elements of local leadership.
\end{abstract}

Keywords: Inner structure; Local wisdom; Nyangahatn Baburukng; Dayak Kanayatn

\begin{abstract}
Abstrak
Nyangahatn Baburukng adalah mantra komunitas Dayak Kanayatn yang diucapkan pada ritual Baburukng sebagai tahap awal dari tradisi berladangan (bahuma). Kajian ini dilakukan untuk memberikan makna yang lebih mendalam terhadap struktur batin dan kearifan lokal Nyangahatn Baburukng dan sebagai alat pewarisan kepada generasi penerus. Objektif kajian dalam penelitian ini adalah penganalisisan terhadap struktur batin dan bentuk-bentuk kearifan lokal dalam Nyangahatn Baburukng. Kajian didasarkan pada teori-teori kearifan lokal, mantra, dan struktur mantra dengan menggunakan metode deskriptif kualitatif, pendekatan objektif dan sosiologi sastra. Hasil
\end{abstract}


penelitian ini menunjukkan bahwa struktur batin teks Nyangahatn Baburukng meliputi (1) Tema meliputi keyakinan kepada Jubata sebagai penolong dan pemberi berkat; cermat membaca tanda-tanda alam (mendengarkan bunyi burung/rasi) untuk menentukan jenis lahan yang cocok untuk berladang (bahuma); persembahan sebagai sarana untuk berkomunikasi dengan Jubata, hantu, setan/iblis; dan bahan-bahan persembahan sebagai simbol dari rasa syukur, pengorbanan, pemulih hubungan, kesucian, dan keikhlasan. (2) Nada meliputi nada bersyukur, nada penyerahan diri, nada sakral; nada memohon, nada bersahabat, dan nada penuh harapan. (3) Rasa meliputi rasa gembira, optimis, kerjasama, kebersamaan, solider, dan penuh berkat. (4) Amanat mantra meliputi manusia harus mampu membangun komunikasi yang baik dengan Jubata, roh para leluhur, dan iblis agar dapat hidup berdampingan dan tidak terganggu oleh kuasa iblis; pelaksanaan ritual Baburukng merupakan wujud kepatuhan pada tradisi dan penyerahan diri sepenuhnya kepada Jubata; kerja sama, kebersamaan, dan solidaritas yang tinggi perlu terus dilestarikan. Bentuk-bentuk kearifan lokal dalam teks Nyangahatn Baburukng meliputi (1) pengetahuan lokal; (2) nilai-nilai lokal; (3) keterampilan dan teknologi lokal; dan (4) unsur kepemimpinan lokal.

Kata-kata kunci: Struktur batin; Kearifan local; Nyangahatn Baburukng; Dayak Kanayatn

\section{Introduction}

This study was motivated by the importance of exploring the forms of local wisdom of the Kanayatn Dayak community. Local wisdom is understood as values that are believed to be true, and become a reference for people's everyday conduct. Furthermore, local wisdom is an entity that determines human dignity which contains elements of intelligence, creativity, and local wisdom from the community elites.

The corpus of this research is Nyangahatn Baburukng, a mantra chanted in the Baburukng ritual by the Kanayatn Dayak community. This ritual is a tradition carried out to start the cycle of farming. This tradition is still practiced faithfully by indigenous people in certain areas in West Kalimantan which is carried out to start farming activities.

The Nyangahatn Baburukng text is already in document form. In previous research, the text has gone through the process of editing and translation from the Dayak Kanayatn language into Indonesian. Changing the form from spoken text to written text is one of preservation forms. Therefore, the written text of the Nyangahatn Baburukng, which has been in the form of a document, needs to be interpreted more deeply by examining the forms of local wisdom contained in Nyangahatn Baburukng.

The aims of this study are: (1) to describe the results of the analysis and interpretation the inner structure in Nyangahatn Baburukng oral literature of Dayak Kanayatn, (2) to describe the results of the analysis and interpretation the forms of local wisdom in Nyangahatn Baburukng oral literature of Dayak Kanayatn.

A similar study was conducted by Nuwa and Yani (2019) with the title Analysis of the Inner Structure of Indigenous Poems of Sikka Krowe Community in the Poto Wua Ta'a Tradition in Sikka Regency, East Nusa Tenggara. Through this research, it can be seen that the inner structure in the poem includes (1) themes (introduction, proposal, family, divinity; (2) romantic tones, gripping tones, intentional or begging tones, possessing tones; (3) joy, sadness, shame; and (4) a mandate which includes maintaining the sanctity of marriage, the duties and responsibilities of the head of the family, being grateful to God, and living in harmony and peace with God's fellow creatures.

Research on mantras was also conducted by Istianingrum and Retnowaty (2018). The conclusion of this research is the structure of the Tipong Tawar Mantra based 
on themes, rhymes, rhythms, stanzas, lines, and diction that uses local languages and is indeed different from the structure in poetry in general.

Another research entitled Revealing Local Wisdom of Soyong Spell by Paser Community was conducted by Mustikawati (2020). Through this research, it is known that Soyong is a mantra that is uttered by the Paser community to God through the intercession of ancestral spirits in order to get protection and help in life. The Soyong Mantra can be used for travel (Soyong Travel) and to give thanks at the time of the glutinous rice harvest called Soyong at the Nampa Ponta ceremony.

Nesi, Rahadi, and Pranowo (2019) in their research concluded that local wisdom in the Takanab oral tradition is manifested through tangible local wisdom in the form of stones and water, woven motifs, and custom home; also through intangible local wisdom in the form of thimbles, parables, advice, and poetry. Each form of local wisdom manifests noble values that reflect the collective cultural appreciation of the Dawan community.

Compared to previous studies, this study does not only focus on the inner structure of the Nyangahatn Baburukng, but also examines the forms of local wisdom contained in it. The forms of local wisdom that have been analyzed and have become research reports can be used to enrich the readers' insight and knowledge and become a means of inheri-tance for the owner of the mantra to the next generation.

Mantra or chanting is interpreted as an expression that contains supernatural powers (Setiawan, 2019). Mantra is also interpreted as a magic sentence that brings magical power to the spellcaster. In line with Setiawan, Yelle (2003:3--9) emphasized that a mantra contains sacred texts and is a means of contemplation or thought, means or thoughts or an instrument of thought.

Mantra or oral literature is usually called oral literature (Andalas and Sulistyorini, 2017). That is, the mantra is spoken and disseminated orally and from generation to generation. In addition, this mantra can also be passed down by way of learning. Generally, mantras are taught by people who have supernatural powers called shamans, bomohs, or handlers. Like-wise, mantras according to Laelasari and Nuralilah (2008:153) are words or expressions that can bring out magical powers uttered by shamans or pawang (spellcaster). So, it can heal, hurt and so on, which aims to match other supernatural powers.

According to Hartata (2010:36) etymologically, the word "mantra" comes from the words "man/manas" and "tra/ tri" which mean to think or protect, especially protecting the mind from evil interference. Meanwhile Hutomo (1991:2-3) stated that mantra is an expression of society's literary of a culture that has been passed on orally by words of mouth.

Roy (2012) said that the mantras were to be used and explanations of the legends connected with the mantras and rituals. Both these portions are termed which was passed on to consecutive generations orally instead of any hand written documentation.

Hamidin (2016) and Nurjamilah (2015) explain that mantras develop in primitive societies. The survival of a spell depends on the level of need in the society that supports it. In general, mantras function in achieving a goal which is carried out with magical activities.

According to Setiadi dan Firdaus (2018), mantras can be categorized in oral literature in the form of folk poetry at that time used as the owner's community as a solution to face life's problems, so that mantras are not only 
aesthetic but also pragmatic. According to Nugraha (2015) one proof that mantras can be used as a solution to life is when the owner of the spell has difficulty, he will recite the mantra to cause a trance.

Local wisdom as a whole cultural characteristic shared by a society as a result of their lifelong experiences. Likewise Rosidi (2011: 9) explained that local wisdom is a translation of local genius. Mariane (2013: 112) explained that local genius shows local identity, the identity of a national cultural personality that allows the nation to be able to absorb and consolidate foreign culture in accordance with its own charac-ters and abilities. According to Permana (2010:2) the system for fulfilling the needs of life includes belief system, knowledge, economy, technology, social organization, language, and art works.

Keraf (2010: 369) mentioned the term local wisdom as traditional wisdom which includes all forms of knowledge, beliefs, understandings or insights as well as customs or ethics that guide human behavior in the life of an ecological community. Considering the elements that make up local wisdom, Ife (2002) stated that local wisdom has five forms (dimensions), such as local wisdom, local values, local skills, local decision-making mechanisms, and solidarity within local groups.

\section{Method}

This qualitative descriptive study aims to explain the visible phenomena and seeks to describe the characteristics of the object under study as they are. Syamsuddin \& Damaianti (2006:24) and Moleong (2017: 6) affirm that data in a qualitative study consists of words, illustrations, and not numbers.

According to Sugiyono (2018:14--15) qualitative research is also referred to as a naturalistic research method and ethno- graphic research based on the philosophy of post-positivism. It is used to examine objects naturally where the researcher as a key instrument; determination of data sources is carried out purposively and snowball. He furthermore suggests that data validity is done by triangulating; inductive data analysis; and research results emphasize meaning rather than general-izations.

The approach in this research is a content analysis approach, meaning research that emphasizes its attention to the message content contained in literary works. The aim is to interpret the content of communication, the content of symbolic interactions that occur in communication events contained in literary works (Ratna, 2006: 49).

Endraswara (2011: 161) claimed that content analysis is a strategy to capture the message of literary works by identifying, interpreting, and compiling inference based on the context in the analyzed literary work.

The source of data in this research is Nyangahatn Baburukng text. The data includes the inner structure and forms of local wisdom in Nyangahatn Baburukng. The technique of testing the validity of the data was carried out by triangulation and persistence of observations.

Guided by the process of content analysis proposed by Endraswara, (2011: 162) he data analysis technique was carried out inductively with the following steps: (a) carefully reading of Nyangahatn Baburukng's text which was processed systematically; (b) identifying inner structures and forms of local wisdom as units of analysis and categorizing them according to the theory used; (c) analyzing and interpreting the inner structure and forms of local wisdom based on the theory referred to; and (e) concluding the results of the analysis and the interpretation of the inner structures and forms of local wisdom in the Nyangahatn Baburukng text. 


\section{Results and Discussion}

The form of the Nyangahatn Baburukng mantra resembles other rhetorical forms of opening, filling, and closing. Nyangahatn Baburukng can be said to be a prayer. The difference is that the prayer structure is not always sequential and systematic, where as in Nyangahatn Baburukng a systematic sequence is found.

According to Sinju (1996: 148) there are four stages performed by a Panyangahatn when reciting this mantra. First is Matic which is the stage of informing. Second is Ngalantekatn which is the stage of inviting Jubata and Awapama. Third is Mipis which is the stage of cleaning and expelling all kinds of diseases and flying them into the sunset, and fourth is Ngadap buis which is the stage of allowing Jubata (God) and other spirits to eat the offerings that have been provided.

Each stage shows a different purpose, but still supports one main goal, such as hearing birds chirping (rasi or animal sign) as an indication that an area or a location is suitable for rice cultivation. In this respect, the areas might be either hills, lowlands, or wetlands.

\subsection{Inner Structure of Nyangahatn Baburukng}

Inner structure of poem (mantra) according to Waluyo (1997: 147) is the meaning contained in the mantra. In addition to the words in a spell that can cause supernatural powers, the mantra also reflects the thought patterns, feelings, attitudes, and imagi-native experiences of its supporters (Maknun, 2012: 55).

Nyangahatn Baburukng is a mantra chanted by a Panyangahatn during the Baburukng tradition. In particular, in this tradition the goal is to listen to the sound of birds, which is believed to be a sign denoting the type of lands suitable for farming in the growing season of that year. The sound of birds (rasi) is believed to be a guide given by Jubata (God) in this ritual activity.

The Dayak Kanayatn community realizes and believes that the power of the Great Jubata can improve human life. In addition, they also believe that there are evil forces in the form of demons and various other venomous beasts that can destroy human life that this evil force must be avoided. Briefly, human life depends on how they relate to these two forces.

Jubata plays a very big role in the life. Jubata creates and controls the entire earth, including all extraordinary natural phenomena that are reflected from the background elements in this mantra such as water centers, ground floor, ends of the sky, hills, mountains, river estuaries, and so on. Jubata is the highest God (Hartini and Fusnika, 2019). Jubata, who created the heavens and the earth, has God-like qualities or God (Putra, 2013). According to Dinata et al (2014), Jubata is considered the highest ruler in the universe. In addition, Jubata is also considered a person (ancestor) who resides in the sky.

In Nyangahatn Baburukng the social structure is illustrated including Tuha Tahutn, Bide Binua, Tuha Ale'atn, Panyanakng Kalangkakng, Timanggong, Pasirah, Pangaraga, Panyangahatn. This structure illustrates that social life related to the implementation of customs and traditions is well ordered and is still being lived and implemented today.

The overlapping arrangement of bamboo symbolizes the bountiful harvest which is expressed in the parable of "padi lama batinih padi barahu" which means old rice is overlapped by new rice. In other words, it is expected that new rice is added before the old rice runs out. In this case, it can be also interpreted that bamboo (solor) symbolizes the optimistic attitude of the Dayak 
Kanayatn community towards Jubata's help in their agricultural activities.

Meanwhile, the offerings at Nyangahatn Baburukng are in the forms of household staples (i.e., rice, sticky rice, chicken, betel) and traditional dishes used in traditional ceremonies and festivals such as tumpi' and poe'. The offerings symbolize gratitude, devotion, loyalty and complete submission to Jubata.

Other symbolic items include Baras Kuning (yellow rice), Baras sasah (washed rice), Minyak (oil), and Langir (hair oil). Yellow rice is believed to be able to dissolve bad things and serves as a fortress or family protector from all kinds of disturbances. Likewise, washed rice can purify all things that are dirty or less decent. Oil and hair-oil are believed to be solvents and antidotes. These three symbolic items symbolize the power and presence of Jubata among humans.

There are similarities between Nyangahatn Baburukng and the mantra Soyong of Paser community. Which is related to the involvement of the spirits of the ancestors in communicating with God through the chanted mantra. Mustikawati (2020) in her article explained that the Soyong mantra is a mantra for the Paser community which is conveyed by means of ancestral spirits to God in order to get care and help for their lives.

Refers to reasearch of Istianingrum and Retnowaty (2018) on the inner structure of mantras and the research of Nuwa and Yani (2019) on the inner structure of poetry, it is known that the inner structure of mantras includes themes, tones, feeings, and mandates.

Based on the results of the analysis of the research data, it is known that the inner structure of the Nyangahatn Baburukng mantra is as follows. (1) Themes include belief in Jubata as a helper and giver of blessings; carefully reading the signs of nature (listening to the sound of the bird/rasi) to determine the type of land suitable for farming (bahuma); offerings as a means to communicate with Jubata, ghosts, demons/devils; and offerings as symbols of gratitude, sacrifice, restoration of relationships, purity, and sincerity. (2) The tone includes gratitude, surrender, sacred; pleading, friendly, and hopeful. (3) The feelings includes joy, optimism, cooperation, togetherness, solidarity, and full of blessings. (4) Mantra's mandate includes that humans must be able to establish good communication with Jubata, the spirits of the ancestors, and the devil so that they can coexist and not be disturbed by the devil's power; the implementation of the Baburukng rirual is a form of obedience to tradition and complete surrender to Jubata; cooperation, togetherness, and high solidarity need to be preserved.

\subsection{Local Wisdom in Nyangahatn Baburukng}

The forms of local wisdom in Nyangahatn Baburukng include local wisdom, local values, local skills and technology, as well as elements of customary leadership. Avonina (2006) stated that local wisdom is also called traditional knowledge, speci-fically, everything that is related to traditional aspects, both in the form of activities and results of work based on certain cultures.

\subsubsection{Local Knowledge}

Permana (2010: 7) explained that traditional knowledge is knowledge that is possessed, controlled, and utilized by a society which is heredity and continues to develop in accordance with environmental changes.

The forms of local knowledge in the mantra of Nyangahatn Baburukng include how to ask Jubata's permission to determine the types of land suitable for planting rice; 
equipment used in Nyangahatn Baburukng; how to commu-nicate with Jubata and ancestral spirits; and knowledge of the characters who played a role in Nyangahatn Baburukng.

The mantra of Nyangahatn Baburukng is recited by a Panyangahatn in a sacred place. This ritual has been carried out for generations and is used to determine the types of field suitable for growing rice. The Baburukng ritual furthermore provides learning in the form of local knowledge to the Dayak Kanayatn community about the preparations and steps that need to be carried out in requesting permission and instructions from Jubata to determine the types of land that is suitable for planting rice. Accordingly, the representation of the instructions given by Jubata can be understood by the Panyangahatn through the sound of a bird (rasi) which signals about the types of soil suitable for planting rice. In the following section is presented a quote recited in Baburukng ritual.

$A u^{\prime}$ kami sabuah kampokng niatn Jubata'a

$k a^{\prime}$ Konyo sakayu' niatn nuna' $a^{\prime}$ napatatn boh unang Jubata'a, nangaratna' rasi. (NB, pgr. 1).

Local knowledge in the Nyangahatn Baburukng mantra also includes knowledge of the equipment used in the ritual such as a plate of rice, a plate of sticky rice, a boiled egg, a bowl of washing water, a soil-oil lamp, yellow rice, a bowl of washed rice, oil and hair oil; tumpi', a plate of sticky rice, chicken, kobet, and cooked betel. In particular, Yellow rice is called 'Penekng Unyit Mata Baras' which serves as a protection or fortress for the family, as an antidote to all kinds of bad things. This following script is related to the meaning of yellow rice.

$A u^{\prime}$ sagala penekng unyit mata baras niatn Jubata'a kami dah nabar nawaria' kade' ada nang bisa nang sahakng nang janga'.
Hega'nya moreatn penekng unyit mata baras nia. (NB, pgr.3).

The water for washing is called $a i^{\prime}$ pasasahatn which functions to clean offerings, seeds, soil, and other things related to the Baburukng ritual.

Iatn boh Jubata'a aku nyasah palawakng antamu banih padi barok, padi tuha niatn.

Koa angkenya kita' aku nyasah kita' nang keatn muanga' daki', gutu', miang (NB, pgr.12).

Langir and oil serve to protect and cleanse the seeds and protect them from all evil. Please refer to this following script.

Iatn boh Jubata'a aku dah ngalangira' au' minyakia'nya. Au' minta' ia lenyok lenso sapati binyak. (NB, pgr.17).

Cucur (tumpi') is a type of snack made from a mixture of rice flour and brown sugar which is fried in a round shape. This snack symbolizes sturdiness or constancy. Meanwhile, $P o e^{\prime}$ is sticky rice-based food stored in bamboo stalks and placed on hot coals, which symbolizes tenderness. In addition, these traditional cookies are used as offerings, treats to guests and people who are respected, and as an expression of gratitude. Therefore, these foods must be always available at the traditional festivals of the Dayak Kanayatn community. Please refer to this following script.

$A u^{\prime}$ iatn kita' sapati $N e^{\prime}$ Baruakng kita' nang barampu' padi baras. Au' kita' makatn paremah tumpi' poe' au' $k a^{\prime}$ atas bantatn pangantar buis kami (NB, pgr.22).

Before being slaughtered, the local chicken (in particular its wings) area used by a Panyangahatn to wag the chicken wings (Mipis) on all attendance in the ritual event. A chicken wing is a symbol to get rid of or blow away all kinds of diseases and bad things.

$A u^{\prime}$ ngiatn kami bapadah unang sapati mipisatn seap manok keatn Jubata'a. Kami ngalumpatatna' patahunan kami Jubata'a 
$k a^{\prime}$ Konyo sakayu'. Jubata'a kita' murasatn baras nang kita' murasatn ka' kami, kami namu padi baras (NB, pgr.24).

Knowledge is the total knowledge possessed by a community living in a particular location, developed because of the need to live, maintain, and carry on life in accordance with the situation, conditions, abilities and values that are lived in the community (Rosyadi, 2014:443). Local knowledge is part of their wise way of life, in order to be able to solve all the problems of life they face, so that they can carry on their lives, in fact, can develop sustainably (Kartawinata, 2011:xi)

Based on the result analysis, the forms of local knowledge in Nyangahatn Baburukng includes: (1) how to read natural signs (bird sounds/rasi); (2) the material and meaning of the offerings used in the Baburukng ritual; (3) how the Panyangahatn communicates with Jubata, the spirits of the ancestors, ghosts, devils or demons; (4) the stages carried out by the Panyangahatn; and (5) the duties and roles of community leaders in the implementation of Nyangahatn Baburukng.

The Baburukng ritual is the first stage that the Dayak Kanayatn community must carry out in the farming cycle (bahuma). By reading the signs of nature (bird sounds/rasi) it is possible to know the type of land suitable for farming (Bahuma) in that year. The tradition of reading natural signs to start farming activities also occurs in the Tapango community in Polewali Mandar. P, Fatmawati (2019:89) reports that by looking at the phenomena that occur in sandalwood trees and randuq trees. The leaves of the two trees will fall in the dry season, but as soon as the rainy season enters, the branches of the two trees begin to leaf again. This then became a sign for the Tapango community in Polewali Mandar that the paddy planting season would soon begin.

\subsubsection{Local Values}

Substantially, local wisdom is the values that apply in a society that are recognized as true and become a reference for people to conduct (Mariane, 2013). The religious values of the Dayak Kanayatn community can be seen through the implementation of rituals in their belief system, and customs affirm their religious identity. In other words, Adat or custom as a belief system is clearly evident when they perform various rituals related to their everyday life.

This community believes in the providence of God in which since its original religion has been called Jubata. Jubata is God who has power over the heavens and the earth and everything in them, over human life and all creatures because of his supernatural powers.

Wulandari (2020) in her article it is concluded that the role of ballads or hymns (or Kidung) during the Mount Sedhekah (offerings) procession serves as a medium for praying to Allah Swt. and asking Him for protection. The same thing in the Dayak Kanayatn, Nyangahatn Baburukng is also a medium for praying and asking for Jubata (God) so that the Baburukng tradition which is performed to determine the types of land suitable for planting and rice fields run smoothly

Expressing their belief in Jubata they visit holy places called panyugu and padagi. Therefore, to carry out the ritual in this sacred place, the community needs a ritual leader named Panyangahatn where Panyangahatn's job is to act as an intermediary between humans (talino) and Jubata (God).Therefore, in religious rituals the name Jubata is always mentioned in order to give blessings, protection, generosity, and even to be present in every event of human life. Jubata is understood through the manifestations of the events of their life. Therefore, the Dayak Kanayatn community 
is always careful to comply with religious and belief norms in order to avoid catastrophe.

Hega' kami make adat niatn bapadah $k a^{\prime}$ kita' Jubata'a. Baiknya sapati ka' awa pama nang ngaramat $k a^{\prime}$ Panyugu $k a^{\prime}$ Kadiaman, $k a^{\prime} a i^{\prime}, k a^{\prime}$ tanah baiknya (NB, pgr. 42).

The Dayak Kanayatn community believes in Jubata, Gods, Awapama (the spirits of the ancestors), and ghosts. The Panyangahatn asks that Jubata and the spirits of the ancestors to give blessings and help to humans (talino). Ghosts (demons) are believed to be those who can cause disease to humans, animals, and plants. Therefore, ghosts or demons need to be given offerings so that they will not wreak havoc on living things and not disturb the rituals or activities that humans carry out. Please refer to the quote as follows.

$A u^{\prime}$ kade' ada ka' diatn jin, buta, setan ibalis angkut-angkut sinyarera nang $k a^{\prime}$ dalapm samut gatal kita'. Kade'nya nang sapati kami maiki' api sapati diatn, kade' kana kita' sapati dibara api, kana bubuhi' diai' angat, ame kita' baaiti rimong baati bongka', kita' baati baik baati gagas. (NB, pgr. 68).

The value of solidarity in the Dayak Kanayatn community can be seen in their togetherness in carrying out the Baburukng ritual. All residents participate in the joy of carrying out this ritual because together with traditional leaders, they will determine the types of agricultural land suitable for planting rice. The Nyangahatn Baburukng ritual is a ritual that is carried out with great hope and has become a tradition that has been carried out from year to year.

$A u^{\prime}$ kami ka' Konyo sakayu', dari aku sampe $k a^{\prime}$ tuha tahutn $k a^{\prime}$ panyanakng $k a^{\prime}$ pangalangok. $A u^{\prime}$ nang ngantaratn kampokng radakng tumpuk Jubata'a nang laki, bini, kamuda' bahuma batahutn a' koa (NB, pgr. 11)
Regarding people who obey their customs, including people with high culture. Muhrotien (2012) stated that obedience to customs is closely related to religious, social and economic aspects. The Baburukng ritual is a ritual that is carried out from generation to generation. So, it can be said that they live the value of obedience which provides benefits and has a positive impact on their success in farming.

$A u^{\prime}$ barampu' adat niatn Jubata'a, koa angkenya sabaya muda', sabaya enek, make ngarace'atn ia sapati da' ne' Dilam Jubata'a. Saga' ia nang patah minta' ia basule, ia baganti, basilih. (NB, pgr. 5).

The value of justice is the value of wisdom which shows that there is balance and fair treatment to anyone in accordance with their rights and dignity. In Nyangahatn Baburukng a statement is found showing that the Panyangahatn asked God to be fair to all residents of Konyo Village regarding farming and rice fields.

$A u^{\prime}$ minta' Jubata'a kade' kami duduk sabaya babah, kade' badiri sabaya tingi. Au' minta sabaya namuan sabaya napatatn Jubata'a. Iatn boh Jubata'a kami bapinta' ka' Jubata Bujakng Pabaras. (NB, pgr, 30).

In the quote, Panyangahatn pleads with Jubata and Bujakng Pabaras to be fair to all residents of Konyo village so that all residents can get abundant crops. Herlina, Kusnita and Hariadi (2021:1246) mention that Jubata and Bujakng Pabaras are mythological figures in the Nyangahatn mantra. Jubata refers to anything that is capable of bringing good to mankind. The mention of Bujakng Pabaras refers to supernatural beings who can help and bring disaster to humans, can also be an intermediary for human communication with supernatural beings around human life.

Based on the results of the analysis, it can be concluded that the local values includes religious values, solidarity values, 
obedience values, and justice values. These local values have been lived for a long time from generation to generation which bring good for personal life and social life, especially in the bahuma batahutn tradition of the Dayak Kanayatn community.

\subsubsection{Skills and Local Technology}

Permana (2010: 4-6) explained that local skills are used by a community as the ability to survive, such as hunting, gathering, farming and making home industries. Local skills are generally related to local technology because local skills require equipment produced by local technology.

In the Nyangahatn Baburukng is known that local skills include the skills to interpret the sound of the bird/rasi. Not to mention the skills of reciting Nyangahatn text and the skills of how to prepare various per-offering materials in the Baburukng ritual are crucial. Although not all of these skills are stated explicitly in the Nyangahatn Baburukng text, they can be identified and observed through the process of carrying out the ritual.

Dunia mula jadi, adat niatn dah mula tumuh boh Jubata'a. Nang make penekng unyit mata baras Jubata'a turutn $k a^{\prime}$ ari nang baik, ka' bulatn nang gagas. Pokoknya kade' ada rasi, au' bakata Jubata'a kita', ngataatn sapati sumangat padi baras (NB, pgr.7).

Other local skills are skills possessed by a Panyangahatn which include spell-reading skills and skills in carrying out Baburukng rituals. Please consider the following quote.

$A u^{\prime}$ Jubata'a, kami nang ngalumpatatna' patahunan niatn. Aku nang dinojok Tuha Tahutn Jubata'a, nang ampaikng Jubata'a, koa angkenya aku turutn $k a^{\prime}$ Panyanakng, $k a^{\prime}$ Pangalangok. Iatn boh Jubata'a sapati nang mampauti' kampokng radakng tumpuk binua nang bini, kamuda', anak, ucu' uyut bauma'a batahutn Jubata'a. (NB, pgr. 30).
A Panyangahatn also has the skill to listen to the sound of birds/ rasi so that he is able to pinpoint the types of soil that are suitable for farming or rice fields.

Au' turutnlah Jubata'a ka' uma tahutn kami. Jubata minta' turutn $k a^{\prime}$ tanah limpahukng, tanah damparatn, tanah pabarasatn. Jubata'a saja' kade'nya rasi nang nojoki', au' dah kami make dah kami ngahiak Jubata'a naik sampe kampokng radakng tumpuk binua (NB, pgr. 29).

Local skills are a set of knowledge, values, behavior, and ways to behave towards certain objects and events in their environment, which are recognized as good and true by the community. The ability to survive (survival) of each community can be met if the community has local skills. Local skills range from the simplest such as hunting, gathering, farming, carrying out rituals to building a home industry. These local skills are also life skills, so these skills are very dependent on the geographical conditions of the place where the community lives. In the text Nyangahatn Baburukng found three skills, namely the skill of listening to the sound of birds/rasi; the skill of reciting the Nyangahatn Baburukng; and skills in preparing the materials for offerings needed in carrying out the Baburukng ritual

The technology that appears in the Nyangahatn Baburukng text is a simple technology related to food processing. Tumpi' and poe' are two types of traditional food that are used as offerings in Baburukng rituals. Tumpi' and poe' are simple processed rice and sticky rice-based cakes or snacks. Despite its simplicity simple, the process of making them shows the creativity of the Dayak Kanayatn com-munity in preparing and serving the additional foods besides rice. $P o e^{\prime}$ is defined as a stick which is a symbol of the ladder that supports human life. Please refer to this following quote. 
Asa', dua, talu, ampat, lima, anam, tujuh... Jubata'a niatn aku nyolo'atn tungkat poe' naing Jubata'a panungkat panukukng buis bantatn keatn Jubata'a. Asalnya lamut poe' ngiatn lambut uga' paridup kami Jubata'a $k a^{\prime}$ Konyo sakayu' baiknya $k a^{\prime}$ tumpuk radakng binua (NB, pgr. 46).

In addition, the Nyangahatn Baburukng text also requires traditional tools in the forms of machetes, axes and pickaxes which were used by Dayak Kanayatn ancestors in farming. This shows that the simple technology used by this community has been well known.

$A u^{\prime}$ kami mulakngia' mata kapak, mata baliukng Jubata'a man mata iso'nya. Au' turutnna' bahuma batahutn. Babatak Jubata'a kami sapati nang $\mathrm{ka}^{\prime}$ keatn nempota' sapati baiknya, au' sapati baiknya kayu, baiknya tungul, baiknya akar, sapati baiknya ui (NB, pgr. 31).

According to Malihah (2010) every society experiences growth and development due to changing needs from time to time. As an implementation of science, traditional societies also have technology that they use in an effort to simplify their lives, is reflected in various forms such as food processing technology, tools for agricultural activities, and the buildings they use (Maknun, 2017). In the Nyangahatn Baburukng found traditional food process-ing technology (tumpi' and poe') and technology related to agricultural tools such as machetes, axes, and pickaxes.

\subsubsection{Elements of Indigenous Leadership}

According to Permana (2010:4-6) each community basically has its own local government which is recognized as a tribal leader. Every society has a different decisionmaking mechanism. There are people who do it democratically or sit the same low, stand the same level. There are also people who carry out these demonstrations in stages.

In Nyangahatn Baburukng it is known that there are several positions related to farming customs. The positions comprise Panyangahatn, Panyanakng Kalangkakng, Tuha Tahutn, Tuha Ale'atn, Bide Binua, Timanggong, and Pasirah or Pangaraga.

Panyangahatn is the priest who recites the mantra. A Panyanakng Kalangkakng is the enforcer of the altar, that is, the person who is responsible for the implementation of traditional rituals in sacred places. While, Tuha Tahutn is the person who is in charge of carrying out the traditional farming rituals. Tuha Ale'atn is the person in charge of arranging group works schedules in the fields. Bide Binua is the person who organizes the implementation of traditional ceremonies at the hamlet level. Timanggong is a customary law enforcement officer, and Pasirah or Pangaraga is the assistant for the Timanggong.

In the Nyangahatn Baburukng not all of these positions are mentioned. However, some are mentioned between lines. Please look through this following quote.

$A u^{\prime}$ iatn ake mare'a' urakng tuha kami bapagalar bapajanang nang are' nang lama. $A u^{\prime} \mathrm{Ne}^{\prime}$ Adi Jaya, Ne' Adi Kusuma, turutn di Ne' Bangka, au' turutn di ne' Rege. Turutn sapati di Ne' Ngangkat, sapati Bide Binua, Pangalangok, Tuha Tahutn. Au' turutna' ka' tuha ale'atn. Iatn nu' kita'. Au' saja' ampeatan kami sapati ganti sule' kita', au' nang patah basule' bajalunukng, nang langit baganti mang adat aturan nang are' nang lama (NB, pgr. 64).

Based on the results of the analysis of local wisdom forms contained in the text of Nyangahatn Baburukng, the four forms of local wisdom can be grouped into two parts, namely local wisdom tangible and intangible. According Dokhi, et al (2016) which says that the form of local wisdom is 
divided into two, namely tangible and intangible. Based on this opinion, it can be said that local skills, local technology, and elements of traditional leadership in the Nyangahatn Babukurng are tangible forms. Local wisdom in the form of local knowledge and values is an intangible form.

\section{Conclusion}

The inner structure of the Nyangahatn Baburukng show that (1) themes include belief in Jubata as a helper and giver of blessings; carefully reading the signs of nature (listening to the sound of the bird/rasi) to determine the type of land suitable for farming (bahuma); offerings as a means to communicate with Jubata, ghosts, demons/devils; and offerings as symbols of gratitude, sacrifice, restoration of relationships, purity, and sincerity. (2) The tone includes gratitude, surrender, sacred; pleading, friendly, and hopeful. (3) The feelings includes joy, optimism, cooperation, togetherness, solidarity, and full of blessings. (4) Mantra's mandate includes that humans must be able to establish good communication with Jubata, the spirits of the ancestors, and the devil so that they can coexist and not be disturbed by the devil's power; the implementation of the Baburukng rirual is a form of obedience to tradition and complete surrender to Jubata; cooperation, togetherness, and high solidarity need to be preserved.

The forms of local wisdom in the Nyangahatn Baburukng text consist of: (a) local knowledge; (b) local values; (c) local skills and technology; and (d) elements of local leadership. Local skills and technology as well as elements of customary leadership are tangible forms of local wisdom, while local knowledge and values are intangible forms of local wisdom.

\section{Referensi}

Andalas, E. F. and Sulistyorini. 2017.Sastra Lisan. Malang: Madani.

Avonina, S. 2006. "Apa yang Dimaksud dengan Pengetahu-an Tradisional?", Konvergensi, IX.

Dinata, A. et al. 2014.Rumah Sehat Jubata, Radakng. Jakarta: Lembaga Penerbitan Balitbangkes.

Dokhi, D. 2016. Analisis Kearifan Lokal Ditinjau dari Keragaan Budaya. Jakarta: PDSPK Kemendikbud RI.

Endraswara, S. 2008. Metodologi Penelitian Sastra. Yogyakarta: MedPress.

Endraswara, S. 2011. Metodologi Penelitian Sosiologi Sastra. Yogyakarta: CAPS.

Hamidin, M. 2016. "Bentuk, Fungsi, dan Makna Mantra Ritual Upacara KASAMBU Masyarakat Muna di Kecamatan Katobu Kabupaten Muna", Jurnal Bahasa (Bahasa dan Sastra).

Hartata, A. 2010. Mantra Pengasihan (Rahasia Cinta dalam Klenik Jawa). Yogyakarta: Kreasi Wacana.

Hartini and Fusnika. 2019. Tradisi Naik Jurong pada Suku Dayak Mualang di Kabupaten Sekadau. Jember: CV Pustaka Abadi. https://doi.org/10.31932/jpk.v4i2.551

Herlina, H., Kusnita, S. and Hariadi, T. 2021. "Tokoh Mitologi dalam Mantra Nyangahatn Ka' Saka' Panen Padi Etnis Dayak di Kalimantan Barat". Journal of Education, Humaniora and Social Sciences (JEHSS), 3(3). doi: 10.34007/jehss.v3i3.531. 
Hutomo, S. S. 1991. Mutiara yang Hilang: Pengantar Studi Sastra Lisan. Surabaya: Hiski Jawa Timur.

Ife, J. 2002. Community Development, Creating Community alternative Vision Analysis and Practice. Australia: Longman.

Istianingrum, R. and Retnowaty, R. 2018. "Tipong Tawar dalam Ritual Pertanian Dayak Paser: Sebuah Bentuk dan Struktur". Lingua Franca:Jurnal Bahasa, Sastra, dan Pengajarannya, 2(1). doi: 10.30651/lf.v2i1.1435.

Kartawinata, A. M. (ed.). 2011. Kearifan Lokal di Tengah Arus Modernisasi. Jakarta: Pusat Penelitian dan Pengembangan Kebudayaan Badan Pengembangan Sumber Daya Kebudayaan dan Pariwisata Kementerian Kebudayaan dan Pariwisata Republik Indonesia.

Keraf, A. S. 2010. Etika Lingkungan Hidup. Jakarta: Penerbit Buku Kompas.

Laelasari and Nuralilah.2008. Kamus Istilah Sastra. Bandung: Nuansa Aulia.

Maknun, J. 2017. "Konsep Sains dan Teknologi pada Masyarakat Tradisional di Provinsi Jawa Barat, Indonesia". Jurnal Indonesia untuk Kajian Pendidikan, 2(2), p. 127-142.

Maknun, T. 2012. Nelayan Makassar: Kepercayaan, Karakter, Identitas. Makassar: Univeristas Hasanuddin. https:// doi.org/10.17509/mimbardik. v2i2.8623

Malihah, E. 2010. "Ilmu Pengetahuan, Teknologi, Seni dalam Kehidupan Manusia". Online http://file.upi.edu/Direktori/DUAL
MODES/PLSBT/Modul_5_PLSBT.pdf.

Mariane, I. 2013. Kearifan Lokal Pengelolaan Hukum Adat. Jakarta: PT Raja Grafindo Persada.

Moleong, L. J. 2017. Metode Penelitian Kualitatif. Bandung: PT Remaja Rosdakarya.

Muhrotien, A. 2012. Rekonstruksi Identitas Dayak. Yogyakarta: TICI Publication.

Mustikawati, A. 2020. "Mengungkap Kearifan Lokal Mantra Soyong Masyarakat Paser". Kantor Bahasa Kalimantan Timur. Available at: https:/ / www.researchgate.net/publicati on/338593854.

Nesi, A., Rahadi, R. . and Pranowo. 2019. "Nilai-nilai Kearifan Lokal Dalam Tradisi Lisan Takanab: Kajian Ekolinguistik". Jurnal Pendidikan dan Kebudayaan Missio. 11, No.1. 71-90.

Nugraha, F. I. 2015. "Mantra Bandung Bondowoso sebagai Tindak Tutur". Jurnal Ilmiah FONEMA: Jurnal Edukasi Bahasa dan Sastra Indonesia. Available at: https://doi.org/10.25139/fn.v1i2.1177.

Nurjamilah, A. S. 2015."Mantra Pengasihan: Telaah Struktur, Konteks, Penutur-an, dan Proses Pewarisannya". Riksa Bahasa.

Nuwa, G. and Yani, A. 2019. "Analisis Struktur Batin Syair Adat Pada Masyaraka Sikka Krowe Dalam Tradisi Poto Wua Ta'a Di Kabupaten Sikka Nusa Tenggara Timur". Mabasan, 13(1). https://doi.org/10.26499/mab.v13i1.244

P, Fatmawati. 2019. "Pengetahuan Lokal Petani dalam Tradisi Bercocok Tanam Padi oleh Masyarakat Tapango Di 
Polewali Mandar". Walasuji: Jurnal Sejarah dan Budaya, 10(1). https://doi.org/10.36869/wjsb.v10i1.41

Permana, R. C. E. 2010. Kearifan Lokal Masyarakat Baduy dalam Mitigasi Bencana. Jakarta: Wedatama Widya Sastra.

Putra, R. M. . 2013 . "Berladang dan Kearifan Lokal Manusia Dayak". Jurnal Ultima Humaniora, 1(2), 160168, 1,No.2. 160-168.

Ratna, N. K. 2006. Teori, Metode dan Teknik Penelitian Sastra. Yogyakarta: Pustaka Pelajar.

Rosidi, A. 2011. Kearifan Lokal dalam Perspetif Budaya Sunda. Bandung: Kiblat Buku Utama.

Rosyadi. 2014. "Sistem Pengetahuan Lokal Masyarakat Cidaun-Cianjur Selatan Sebagai Wujud Adaptasi Budaya". Jurnal Patanjala, Volume 6, pp. 431-446. https:/ / doi.org/10.30959/ptj.v6i3.173

Roy, P. 2012. "Folk-Culture in Vedic Literaturs". Indian Streams Research Journal, Vol. 1, p. pp.1-5.

Setiadi, D., \& Firdaus, A. 2018. "Teks Mantra Embeung Beurang Seputar Kehamilan dan Kelahiran Bayi di Cidolog Kabupaten Sukabumi". Paramasastra: Jurnal Ilmiah Bahasa Sastra dan Pembelajarannya. doi: https://doi.org/10.26740/parama.v1i21489.
Setiawan, E. 2019. KBBI - Kamus Besar Bahasa Indonesia Daring

Sinju, H. B. et al. 1996. Tradisi Peladangan Dayak Kanayatn Binua Kaca' Kecamatan Menjalin Kabupaten Pontianak, Kalimantan Barat. Pontianak: IDRD.

Sugiyono, D. 2018. Metode Penelitian Kuatintatif, Kualitatif dan $R \mathcal{E}$ D. Bandung: Alfabeta.

Syamsuddin and Damaianti, V. S. 2006. Metode Penelitian Pendidikan Bahasa. Bandung: PT Remaja Rosdakarya.

Waluyo, H. J. 1997. Teori dan Apresiasi Puisi. Jakarta: Erlangga.

Wulandari, W. 2020. "Kearifan Lokal Masyarakat Lereng Merapi dalam Kidung Tradisi Sedhekah Gunung: Kajian Antropolinguistik". Tesis. Universitas Sanata Dharma.

Yelle, R. A. 2003. Explaining Mantras. New York and London: Routledge. https://doi.org/10.4324/9780203483381 